\title{
Teachers and students' perceptions of code switching in aviation language learning courses
}

\author{
Rasouli, Abdolaziz \\ English Department, Najafabad Branch, Islamic Azad University, Najafabad, Iran (aziz_r60@yahoo.com) \\ Simin, Shahla $\bowtie$ \\ English Department, Najafabad Branch, Islamic Azad University, Najafabad, Iran (shahlasimin@yahoo.com)
}

Received: 5 June 2015

Revised: 27 June 2015

Available Online: 30 August 2015

DOI: $10.5861 /$ ijrsll.2015.1259

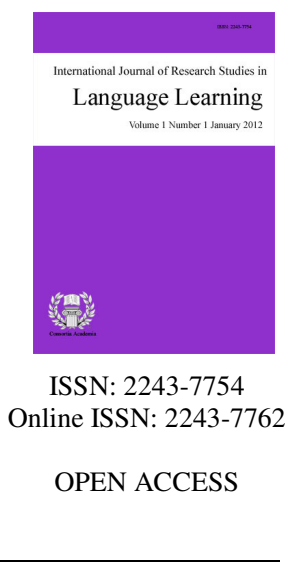

\section{Abstract}

Code switching, the case of switching between two languages during the course of a conversation, has sparked much interest in the field of second language acquisition in general and in foreign language instruction, in particular. This research conducted a survey among students and teachers in aviation training center in Isfahan, Iran. The aim of the research was to assess the students and teacher's perceptions of code switching and to determine whether there were certain factors influencing these perceptions and attitudes. The study investigated forty three medium English proficient students and seven teachers at the English language learning course. A set of questionnaire containing 20 items utilizing 5-points Likert-type scale and interview were managed to quantify the attitude of code switching in classrooms. The study found that most of the teacher interviewed, "sometimes" used code switching mainly to explain difficult concepts and when they feel their students did not understand the materials. The students and teachers' perceptions of teachers' code switching were mostly the same about the subjects related to teacher's persona and subject access and their opinions were not in line about the subjects related to classroom management and interpersonal relation. Although code switching is considered as a medium of instruction in an EFL classroom, but research has shown the negative attitudes of learners towards their teachers' too much using of code switching.

Keywords: code switching; perceptions; attitudes; EFL class; aviation 


\section{Teachers and students' perceptions of code switching in aviation language learning courses}

\section{Introduction}

According to Clyne (1987), code switching is a change by a speaker of a language or language variety to another. It can take place in many situations, for instance when a speaker asks his or her question in one language while the other person answers in a different language or variety. Code switching can happen between sentences or sometimes in the same sentence: "the alternation of two languages at the word, phrase, clause, and sentence levels" Valdés-Fallis (1976, p. 112). Code switching is a conversational strategy used to establish, cross or destroy group boundaries, to create, evoke or change interpersonal relations with their rights and obligations (Gal, 1979).

Heller (1988) adds code switching is "the use of more than one language in the course of a single communicative episode" (p. 1). Auer (1984) refers to "the alternating use of more than one language" (p. 1), while Myers-Scotton (2006) mentions "the use of two or more languages in the same conversation" (p. 7). Romaine (1995) points out Gumperz (1982) as the source of this definition. However, these definitions introduce an element not strictly present in Gumperz's definition: "Conversational code switching can be defined as the juxtaposition within the same speech exchange of passages of speech belonging to two different grammatical systems or subsystems" (Gumperz, 1982, p. 59).

The main focus here is to study code switching in the field of education, in other words, the correlation between code switch and English teachers' and students' perception in aviation English class. The main concern should be focused here is the fundamental concept of code switching to gain a better insight into code switch and it roles in terms of education. Aviation students need to end up proficient English users in order to access knowledge and data accessible in English to have capability for communicate effectively, accordingly recommending the imperative position the students may hold in the future. For this, definitely they must get used to the English language itself.

\subsection{Significance of the Study}

Over the past years, in Iran, a number of studies on code switching have been done, so far, not a lot of researches have been carried out to study code switching in aviation in Iran. Hence, this study was significant because it provided a new breadth for code switching in aviation instruction language learning. This research was apparently one of the first few attempts to investigate code switching in the teaching of English as a foreign language to aviation's students. Therefore, this study may provide a useful basis for further research in this field of interest towards teachers in such situations. If the teachers consider code switching during L2 classes as part of their instruction, as effective teaching strategy in the teaching of English they can play an active and valuable role in helping the students to become more successful in learning courses of English major. This study will be useful for aviation language institutes and universities.

\section{Literature Review}

Bloom and Gumperz (1972) are considered the pioneer researchers in code switching. They view code switching optimistically and were the first to adopt a positive view of code switching. In their study on language use through observation and analysis of tape recordings in a Norwegian fishing discussed and the language situation the speakers found themselves in. On the other hand, Valdés-Fallis (1976), Poplack (1980) and Gumperz (1982) came up with the classifications of code switching functions, direct quotations, emphasis, clarification or elaboration, contextual switches, lexical need switches, triggered switches and others. 
It has been argued that English Only classroom would only lead to frustration since the input is incomprehensible to the learners (Lai, 1996; Brice \& Roseberry-McKibbin, 2001; Widdowson, 2003). Code switching should not be considered as a sign of defect in the teacher. Instead, it is a careful strategy employed by the teachers. In addition, Ting (2007) indicated that it is important to attend to differences in length of language alternations because there appears to be a functional difference between short and long code switches. His observations of two L2 teachers in Chinese universities suggest that short code switches tended to have an intra-sentential form, serving as brief moments of translations (with repeats and paraphrases) that easily fit within the communicative purposes of classroom instructions in which the L2 is maintained as the dominant or matrix language.

Badrul Hisham and Kamaruzaman (2009) performed a study on the learners' perceptions of the teachers' code switching in English Language classrooms in Malaysia. The goals of their research were to examine, a) learners' perceptions of teachers' code switching, b) the relationship between teachers' code switching and learners' affective support, c) the relationship between teachers' code switching and learners' learning success and d) the future use of code switching in students' learning. The study explored 257 low English proficient learners going to Communication 1 proficiency course in a public university in Malaysia. They found that learners perceived code switching as a positive method because of the different capacities it has. There are significant relationships between (1) teachers' code switching and learners' affective support and (2) teachers' code switching and learners' learning success. Learners also demonstrated positive support for future code switching in the English classrooms. It is firmly accepted that teachers' code switching is an powerful teaching method when dealing with low English proficient learners.

\section{Methodology}

This study seeks to answer the following research questions:

$>$ What are teachers' perceptions of the use of code switching to facilitate comprehension in the Language Aviation instruction?

$>$ What are students' perceptions of the use of code switching to facilitate comprehension in the Language Aviation instruction?

$>$ In what circumstances does code switching occur in classrooms?

$>$ Is there any relationship between teachers' perceptions and students' perceptions of teacher's code switching?

\subsection{Participants}

The sample for this study was based on convenient sampling which means that the samples selected based on their possession on targeted characteristics and availability. There were 43 students from three classes chosen on the basis of purposive sampling. Because there were not any female in these classes all the participants were male. The age of the learners ranged from 20 to 25 . All of the learners speak Persian as their first language (L1). The level of their proficiency was intermediate. Two factors of age and level were taken into consideration and served to homogenize the findings. The teachers were selected randomly. Four teachers were at graduate and three teachers were at undergraduate level, all native speakers of Persian, participated in the interviews and filled in the Teacher Code switching Questionnaire.

\subsection{Instrument}

Two types of instrumentations were utilized:

Questionnaires - The modified version of Mingfa's (2011) questionnaire was utilized for both teachers and 
students. It consisted of two main sections; introduction to the survey and leading questions. The first section was about demographic data and the other had four part including twenty items. In the second section, there were twenty questions on the attitudes to the teachers' code switching in classroom to find out how teachers switch codes and when and why they code switch and the most frequent use of Persian for what functions. The questionnaire was modified to include a 5-point Likert-type scale. The scale was comprised as follows; Strongly Agree, Agree, Not sure, Disagree, and Strongly Disagree.

Interviews - To address the research questions, especially the third question, how much teacher's code switching exist in classrooms and in what circumstances does CS occur? Researcher employed a semi-structured interview strategy to ask sets of questions of all the teachers. There are four major areas for the interview questions:

$>\quad$ The teaching background.

$>$ The philosophy of teaching.

$>\quad$ The percentage of $\mathrm{L} 1$ use in class.

$>$ The students' comprehension of the teacher's English use.

Validity and Reliability - To ensure the content validity of the questionnaires and interviews that were mentioned in the previous sections, teachers and students' questionnaire and teachers' interview, the comments of three experts were sought. In addition, to estimate how reliable these instruments were, the researcher relied on the internal consistency computed by Mingfa (2011) to determine the degree of internal consistency based on the Cronbach's alpha. As the acceptable reliability is more than 0.60, and as Mingfa (2011) confirmed, The Cronbach alphas were 0.852 and 0.713 respectively for teacher questionnaire and student questionnaire, which indicate that the reliability in teacher questionnaire is very high, while the reliability is acceptable in student questionnaire. So it can be said that the questionnaires were reliable enough to be used for data collection in the present study.

\subsection{Procedure}

For the first type of data, the questionnaires (Appendix A) were distributed after a brief introductory talk in which the completion procedure was explained to the students. For the second type of data (the teachers' information) the researcher interviewed all the seven teachers one by one to reduce interferences between them and their answers (Appendix B). The interviews were audio tape recorded and the medium of the language was in Persian. All the interview sessions were at least twenty minutes. After interviews the questionnaires (Appendix A) were give them to complete.

\subsection{Data analysis}

The researcher used both qualitative and quantitative method to analyze data. The analytical techniques of data were statistical based on questionnaires and interviews. Based on the questionnaires' outcome, the data was analyzed quantitatively using SPSS to conduct frequencies and percentages. The data was presented in tables. The tables show the percentages needed. The data collected from the teachers' questionnaire was analyzed in relation to the purpose of the study. Also in order to answer the research question 4, to compare the students and teachers' attitudes towards using teachers' code switching in the class, their answers for each part of the questionnaire was compared using bar diagrams. The information recorded from the audio tapings of the semi-structured interview transcribed and the data coded and analyzed via cross-case analysis. That is, the common answers given by the teachers were listed to identify the general tendencies. Then, each response for the questions was analyzed and grouped under related headings. Finally, the results were presented in frequency tables. Moreover, if the quotations borrowed from the teachers were in Persian, they were translated into English by the researcher. 


\section{Results}

\subsection{Quantitative Section: Students' Questionnaire}

\section{Table 1}

Students' Perception of their Teachers' Use of Code Switching

\begin{tabular}{ccccccccccc}
\hline \multirow{2}{*}{ Items } & 1 & $\begin{array}{c}\text { Strongly } \\
\text { Agree }\end{array}$ & 2 & Agree & 3 & Not Sure & 4 & Disagree & 5 & $\begin{array}{c}\text { Strongly } \\
\text { Disagree }\end{array}$ \\
\cline { 2 - 10 } & $\mathrm{f}$ & $\%$ & $\mathrm{f}$ & $\%$ & $\mathrm{f}$ & $\%$ & $\mathrm{f}$ & $\%$ & $\mathrm{f}$ & $\%$ \\
\hline 1 & 2 & $4.6 \%$ & 6 & $13.9 \%$ & 2 & $4.6 \%$ & 23 & $53.4 \%$ & 10 & $23.2 \%$ \\
2 & 11 & $25.5 \%$ & 20 & $46.5 \%$ & 5 & $11.6 \%$ & 5 & $11.6 \%$ & 2 & $\% 4.6$ \\
3 & 5 & $11.6 \%$ & 15 & $34.8 \%$ & 6 & $13.9 \%$ & 14 & $32.5 \%$ & 3 & $6.9 \%$ \\
4 & 10 & $23.25 \%$ & 20 & $46.5 \%$ & 4 & $9.3 \%$ & 7 & $16.2 \%$ & 2 & $\% 4.6$ \\
5 & 2 & $4.6 \%$ & 10 & $23.25 \%$ & 4 & $9.3 \%$ & 18 & $41.8 \%$ & 9 & $20.9 \%$ \\
6 & 11 & $25.5 \%$ & 5 & $11.6 \%$ & 7 & $16.2 \%$ & 15 & $34.8 \%$ & 5 & $11.6 \%$ \\
7 & 8 & $18.6 \%$ & 18 & $41.8 \%$ & 3 & $6.9 \%$ & 10 & $23.25 \%$ & 4 & $9.3 \%$ \\
8 & 11 & $25.5 \%$ & 20 & $46.5 \%$ & 2 & $\% 4.6$ & 7 & $16.2 \%$ & 3 & $6.9 \%$ \\
9 & 5 & $11.6 \%$ & 15 & $34.8 \%$ & 5 & $11.6 \%$ & 11 & $25.5 \%$ & 7 & $16.2 \%$ \\
10 & 6 & $13.9 \%$ & 18 & $41.8 \%$ & 5 & $11.6 \%$ & 10 & $23.25 \%$ & 4 & $9.3 \%$ \\
11 & 8 & $18.6 \%$ & 14 & $32.5 \%$ & 4 & $9.3 \%$ & 10 & $23.25 \%$ & 7 & $16.2 \%$ \\
12 & 6 & $13.9 \%$ & 10 & $23.25 \%$ & 3 & $6.9 \%$ & 17 & $39.5 \%$ & 7 & $16.2 \%$ \\
13 & 11 & $25.5 \%$ & 20 & $46.5 \%$ & 2 & $\% 4.6$ & 6 & $13.9 \%$ & 4 & $9.3 \%$ \\
14 & 8 & $18.6 \%$ & 16 & $37.2 \%$ & 4 & $9.3 \%$ & 8 & $18.6 \%$ & 7 & $16.2 \%$ \\
15 & 9 & $20.9 \%$ & 20 & $46.5 \%$ & 2 & $\% 4.6$ & 8 & $18.6 \%$ & 4 & $9.3 \%$ \\
16 & 8 & $18.6 \%$ & 12 & $27.9 \%$ & 3 & $6.9 \%$ & 13 & $30.2 \%$ & 7 & $16.2 \%$ \\
17 & 8 & $18.6 \%$ & 17 & $39.5 \%$ & 5 & $11.6 \%$ & 8 & $18.6 \%$ & 5 & $11.6 \%$ \\
18 & 7 & $16.2 \%$ & 18 & $41.8 \%$ & 4 & $9.3 \%$ & 12 & $27.9 \%$ & 2 & $\% 4.6$ \\
19 & 8 & $18.6 \%$ & 19 & $44.1 \%$ & 1 & $2.3 \%$ & 11 & $25.5 \%$ & 4 & $9.3 \%$ \\
20 & 11 & $25.5 \%$ & 24 & $55.8 \%$ & 1 & $2.3 \%$ & 6 & $13.9 \%$ & 1 & $2.3 \%$ \\
\hline
\end{tabular}

The results of students' answers to the first part of the questionnaire, teachers' persona, in Table 1 showed that most of the students (about 76\%) disagreed or strongly disagreed that Code switching enables the teachers to express themselves clearly in both languages because they may cause difficulty in comprehending. Half of them believed that teachers' code switching demolishes both languages (English and Persian) and half of them disagreed. Most of them (70\%) believed that teachers who code switch from English to Persian are not proficient in English.

The results of students' answers to the second part of the questionnaire, subject access, in Table 1 showed that half of the participants believed that teachers who switch codes from Persian to English or from English to Persian can do so in all kinds of topics in class and the rest disagreed. Most of them indicated that teachers who use code switching can better clarify the syntactic focuses and lexical things and social items in the content. Half of the answers agreed that teachers' code switching can elicit responses from students and the rest disagreed. Most of them believed that teachers' code switching can better clarify the lesson content taught and task instruction.

The results of students' answers to the third part of the questionnaire, class management, in Table 1 showed that most of them disagreed or strongly disagreed that code switching help teachers better discipline the students but it can engage students' attention. They said that teachers who switch codes from English to Persian can better request quiet and direct students. About the fourth part of the questionnaire, interpersonal relations, as showed in Table 1, about $50 \%$ of the participants indicated teachers who switch codes from English to Persian can better encourage students, but the rest disagreed. In the last four questions of the questionnaire, most of the students agreed or strongly agreed that teachers who switch codes from English to Persian can better praise students, enliven the atmosphere of class (e.g. make a joke for humor), comment on the students' responses, and negotiate 
Rasouli, A., \& Simin, S.

with students (reduce distance).

\subsection{Teachers' Questionnaire}

Table 2

Teachers' Perception of their Teachers' Use of Code Switching

\begin{tabular}{|c|c|c|c|c|c|c|c|c|c|c|}
\hline \multirow[t]{2}{*}{ Items } & 1 & $\begin{array}{c}\text { Strongly } \\
\text { Agree }\end{array}$ & 2 & Agree & 3 & Not Sure & 4 & Disagree & 5 & $\begin{array}{l}\text { Strongly } \\
\text { Disagree }\end{array}$ \\
\hline & $\mathrm{f}$ & $\%$ & $\mathrm{f}$ & $\%$ & $\mathrm{f}$ & $\%$ & $\mathrm{f}$ & $\%$ & $\mathrm{f}$ & $\%$ \\
\hline 1 & 1 & $14.28 \%$ & 1 & $14.28 \%$ & 0 & $0 \%$ & 3 & $42.87 \%$ & 2 & $28.57 \%$ \\
\hline 2 & 2 & $28.57 \%$ & 3 & $42.85 \%$ & 0 & $0 \%$ & 1 & $14.28 \%$ & 1 & $14.28 \%$ \\
\hline 3 & 1 & $14.28 \%$ & 3 & $42.85 \%$ & 0 & $0 \%$ & 2 & $28.57 \%$ & 1 & $14.28 \%$ \\
\hline 4 & 2 & $28.57 \%$ & 4 & $57.14 \%$ & 0 & $0 \%$ & 1 & $14.28 \%$ & 0 & $0 \%$ \\
\hline 5 & 1 & $14.28 \%$ & 2 & $28.57 \%$ & 0 & $0 \%$ & 3 & $42.87 \%$ & 1 & $14.28 \%$ \\
\hline 6 & 1 & $14.28 \%$ & 1 & $14.28 \%$ & 0 & $0 \%$ & 3 & $42.87 \%$ & 2 & $28.57 \%$ \\
\hline 7 & 2 & $28.57 \%$ & 3 & $42.85 \%$ & 0 & $0 \%$ & 1 & $14.28 \%$ & 1 & $14.28 \%$ \\
\hline 8 & 2 & $28.57 \%$ & 3 & $42.85 \%$ & 0 & $0 \%$ & 1 & $14.28 \%$ & 1 & $14.28 \%$ \\
\hline 9 & 0 & $0 \%$ & 1 & $14.28 \%$ & 0 & $0 \%$ & 4 & $57.14 \%$ & 2 & $28.57 \%$ \\
\hline 10 & 1 & $14.28 \%$ & 2 & $28.57 \%$ & 1 & $14.28 \%$ & 2 & $28.57 \%$ & 1 & $14.28 \%$ \\
\hline 11 & 1 & $14.28 \%$ & 1 & $14.28 \%$ & 1 & $14.28 \%$ & 3 & $42.85 \%$ & 1 & $14.28 \%$ \\
\hline 12 & 1 & $14.28 \%$ & 1 & $14.28 \%$ & 0 & $0 \%$ & 4 & $57.14 \%$ & 1 & $14.28 \%$ \\
\hline 13 & 1 & $14.28 \%$ & 2 & $28.57 \%$ & 0 & $0 \%$ & 3 & $42.85 \%$ & 1 & $14.28 \%$ \\
\hline 14 & 1 & $14.28 \%$ & 2 & $28.57 \%$ & 0 & $0 \%$ & 3 & $42.85 \%$ & 1 & $14.28 \%$ \\
\hline 15 & 0 & $0 \%$ & 1 & $14.28 \%$ & 0 & $0 \%$ & 5 & $71.42 \%$ & 1 & $14.28 \%$ \\
\hline 16 & 0 & $0 \%$ & 2 & $28.57 \%$ & 0 & $0 \%$ & 3 & $42.85 \%$ & 2 & $28.57 \%$ \\
\hline 17 & 1 & $14.28 \%$ & 1 & $14.28 \%$ & 0 & $0 \%$ & 3 & $42.85 \%$ & 2 & $28.57 \%$ \\
\hline 18 & 1 & $14.28 \%$ & 4 & $57.14 \%$ & 0 & $0 \%$ & 2 & $28.57 \%$ & 0 & $0 \%$ \\
\hline 19 & 1 & $14.28 \%$ & 1 & $14.28 \%$ & 0 & $0 \%$ & 3 & $42.85 \%$ & 2 & $28.57 \%$ \\
\hline 20 & 1 & $14.28 \%$ & 5 & $71.42 \%$ & 0 & $0 \%$ & 1 & $14.28 \%$ & 0 & $0 \%$ \\
\hline
\end{tabular}

The results of the teachers' questionnaire in Table 2 showed that in the first part of the questionnaire that was about teacher's persona, most of the teachers (about 70\%) disagreed or strongly disagreed that teachers who switch codes from English to Persian or from Persian to English can express themselves clearly in both languages because they may cause difficulty in understanding. Half of them believed that teachers' code switching pollutes both languages (English and Persian) and half of them disagreed. Most of them (70\%) agreed that teachers who code switch from English to Persian are deficient and not proficient in English.

The results of the teachers' questionnaire in Table 2 showed that in the second part of the questionnaire that was about subject access, most of the teacher participants believed that teachers who use code switching can do so in a wide range of points in class. Most of them indicated that teachers who switch codes from English to Persian can better explain the grammatical points and lexical and cultural items in the text. The results of the teachers' questionnaire in Table 2 showed that in the third part of the questionnaire that was about class management, most of the participants disagreed that teachers' code switching can elicit responses from students and can better clarify the task instruction. About half of them agreed that teachers' code switching can better clarify the lesson content taught but the rest disagreed. Most of them disagreed or strongly disagreed that code switching help teachers better discipline the students. The number of teachers who said that teachers who use code switching can better demand quiet and engage students' attention was equal to those who disagreed.

About the interpersonal relations, in the fourth section of the questionnaire, most of the participants indicated teachers who use code switching cannot better support students. In the last four questions of the questionnaire, most of the teacher participants agreed or strongly agreed that teachers who switch codes from English to Persian can better enliven the atmosphere of class (e.g. make a joke for humor), and negotiate with students (reduce distance). Against, most of them disagreed or strongly disagreed that teachers who use code switching acclaim students, and remark the students' responses and reactions. 


\subsection{Relationship between students and teachers' perceptions}

In order to answer the forth research question, the answers of students and teachers were compared in the following section through creating bar diagrams for each part separately:

Research question 4 - Is there any relationship between teachers' perceptions and students' perceptions about teacher's code switching?

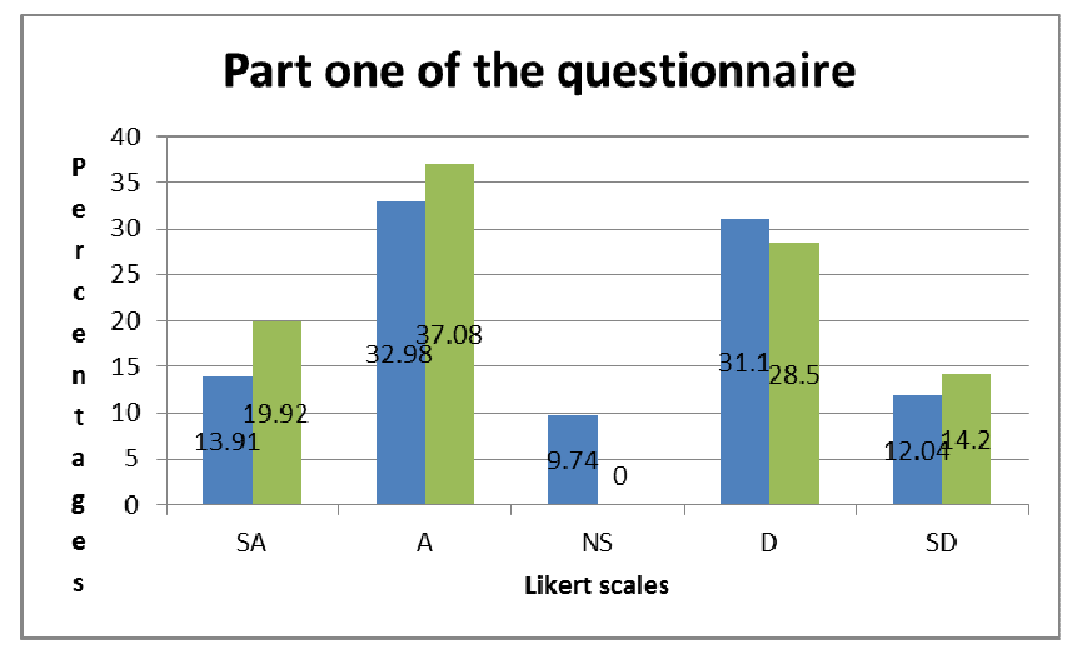

Figure 1 Participants' answers to the first part of the questionnaire (teachers' persona)

Note $:$ Blue $=$ students, Green $=$ teachers

Comparing the answers of teachers and students to the first part of the questionnaire-teachers'-persona showed that teachers more agreed and strongly agreed on the positive relation of teachers' code switching with teachers' persona.

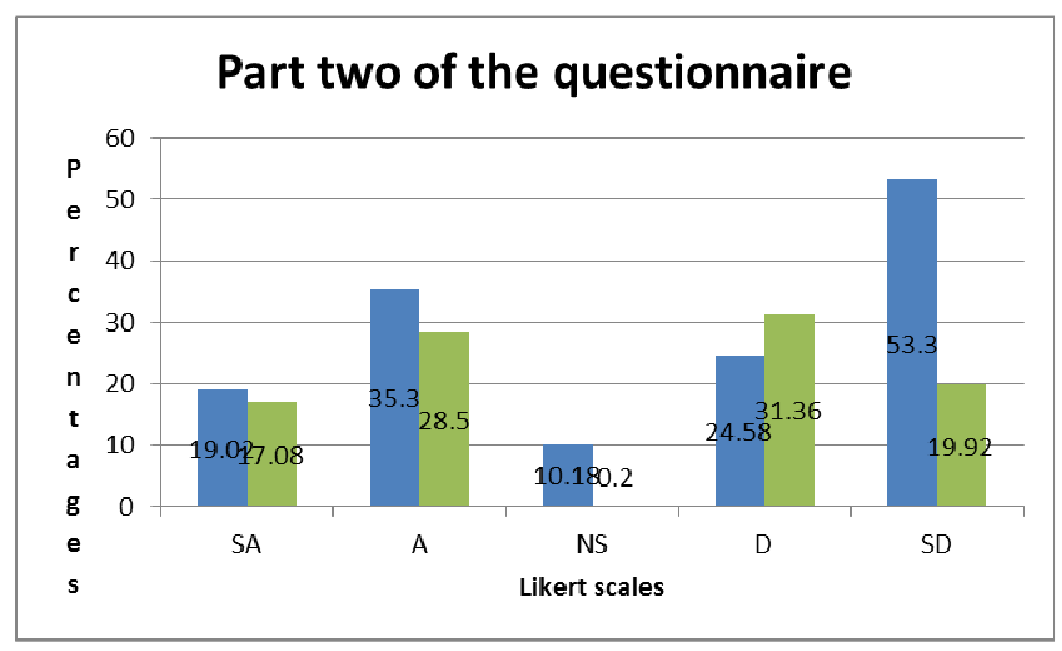

Figure 2 Participants' answers to the second part of the questionnaire (subject access)

Note $:$ Blue $=$ students, Green $=$ teachers

Looking at figure 2 showed that in comparing students and teachers' answers to the second part of the questionnaire, i.e. subject access, the most prominent point to mention is that students more than teachers strongly disagreed about the relationship between their teachers' using code switching and subject access. 


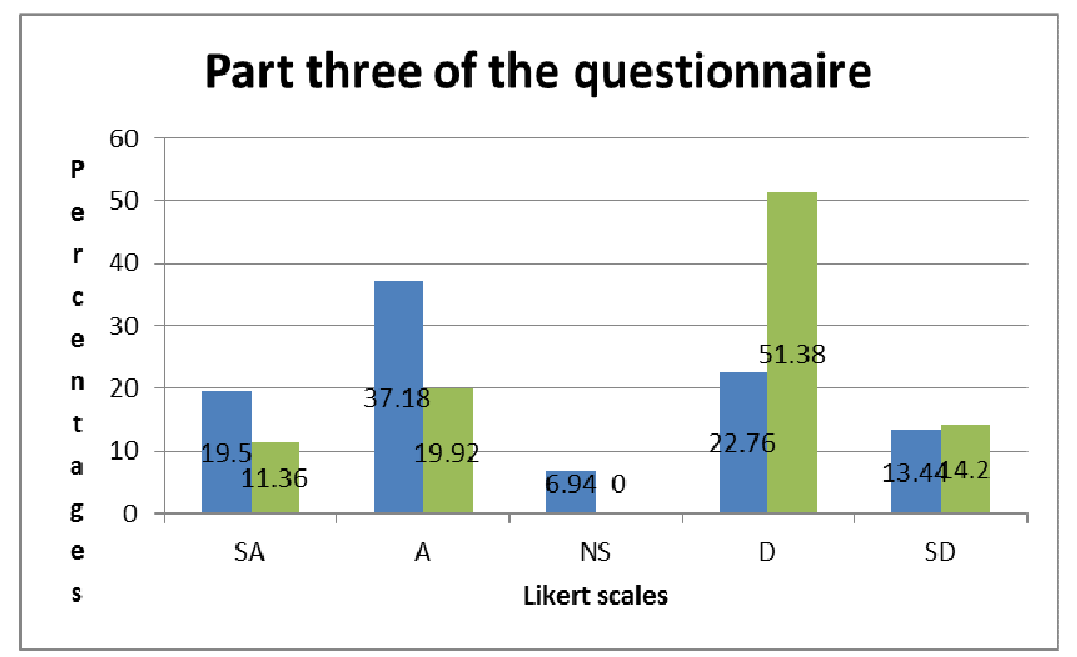

Figure 3 Participants' answers to the third part of the questionnaire (classroom management)

Note $:$ Blue $=$ students, Green $=$ teachers

Comparing the answers of teachers and students to the third part of the questionnaire-classroom management it revealed that students mainly agreed and strongly agreed about the positive effects of teachers' code switching on classroom management, but the teachers mainly disagreed.

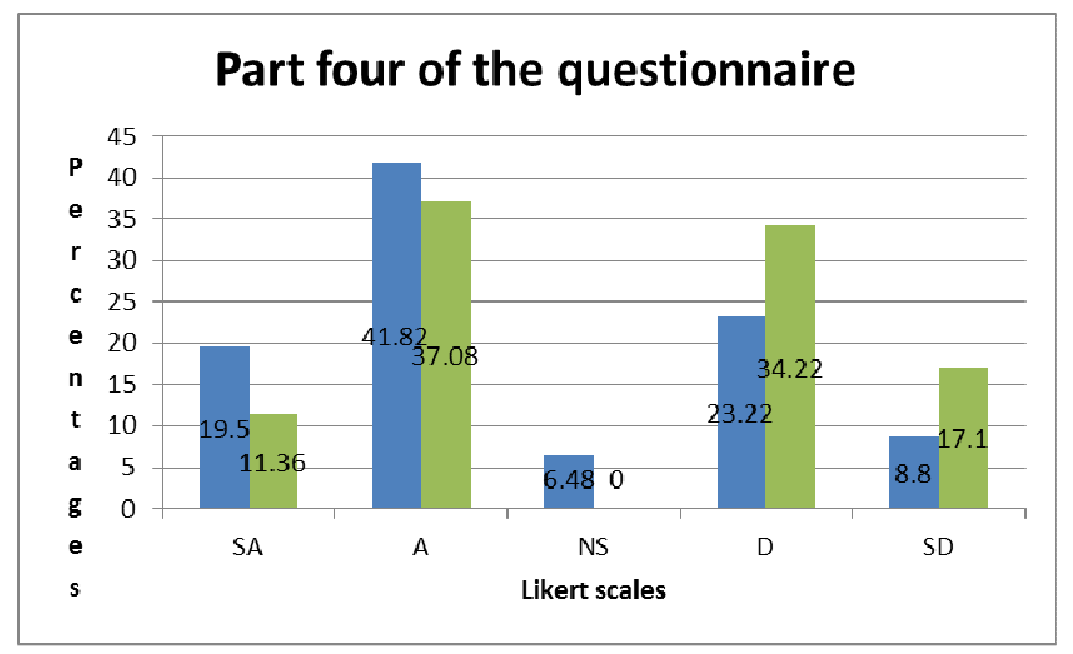

Figure 4 Participants' answers to the fourth part of the questionnaire (interpersonal relations)

Note $:$ Blue $=$ students, Green $=$ teachers

Comparing the answers of teachers and students to the last part of the questionnaire- interpersonal relationsrevealed that students agreed and strongly agreed about the relationship of teachers' code switching and interpersonal relations, but in contrast, the teachers mainly disagreed and strongly disagreed.

\subsection{Qualitative Section: Teachers' Interview}

The interview contained seven questions (Appendix B). Responses to the interview questions were analyzed via cross-case analysis. The results of the responses to each of interview questions are presented in the following tables: 
Table 3

The Results of Teachers' Interview (Question 1)

\begin{tabular}{lc}
\hline \multicolumn{1}{c}{ How long have you been teaching English? } & Frequency \\
\hline Less than 10 years & 2 \\
Between 10-20 years & 3 \\
More than 20 years & 2 \\
\hline
\end{tabular}

As shown in Table 3, most of the interviewees had between ten to twenty years of experience for teaching in universities.

Table 4

The Results of Teachers' Interview (Question 2)

\begin{tabular}{lc}
\hline What kind of course are you responsible for? & Frequency \\
\hline General English courses & 7 \\
specific English courses & 4 \\
\hline
\end{tabular}

Table 4 showed that most of the participants of interview section were university instructors teaching general English courses.

Table 5

The Results of Teachers' Interview (Question 3)

\begin{tabular}{lc}
\hline \multicolumn{1}{c}{ What is your philosophy of teaching? } & Frequency \\
\hline meaningful learning & 3 \\
life-long learning & 2 \\
transformational learning & 3 \\
critical thinking & 2 \\
encourage mastery & 4 \\
\hline
\end{tabular}

In the third question of the interview, as is evident in Table 5, they were asked about their philosophy of teaching. Most of them mentioned their philosophy for encouraging their students to mastery education.

\section{Table 6}

The Results of Teachers' Interview (Question 4)

\begin{tabular}{lc}
\hline How do you manage your language use in the classroom during language instruction? & Frequency \\
\hline Repeating what the student said in his L1 language to English & 4 \\
Asking students to say the sentence in English & 3 \\
Asking the students to explain in Persian what they want to say in English & 1 \\
Answering in English the students' questions that are asked in Persian & 5 \\
\hline
\end{tabular}

In the fourth question of the interview, as shown in Table 6, they were asked about managing language use in the classroom during language instruction by teachers. Most of them stated that when their students ask questions in Persian, they answered the mentioned question in English in order to lead the rest of the conversation in English.

\section{Table 7}

The Results of Teachers' Interview (Question 5)

\begin{tabular}{lc}
\hline \multicolumn{1}{c}{ When do you use L1 in class? } & Frequency \\
\hline In teaching grammar & 3 \\
In encouraging students & 2 \\
When I feel they did not understand the materials & 4 \\
When I teach new vocabularies & 1 \\
To explain difficult concepts & 5 \\
When the students make errors & 1 \\
\hline
\end{tabular}


In the fifth question of the interview, as shown in Table 7, they were asked about the time of using L1 (Persian) in their classrooms. The answers showed that most of them prefer to use L1 when they feel their students did not understand the materials or when their students make errors.

The question six asked the teachers about the amount of using L1 (Persian) in their classes. As their answers were mainly based on the amount adverbs, so they are categorized in four categories: a little, very much, never, and sometimes. The results are shown in Table below:

Table 8

The Results of Teachers' Interview (Question 6)

\begin{tabular}{lc}
\hline \multicolumn{1}{c}{ How much L1 do you use in class? } & Frequency \\
\hline A little & 2 \\
Very much & 1 \\
Never & 0 \\
Sometimes & 4 \\
\hline
\end{tabular}

The last question (question seven) asked the teachers: "Do you think your students can understand the content of your class?" As their answers were mainly positive or negative, so they are categorized in two categories: Yes and No. The results are shown in Table below:

\section{Table 9}

The Results of Teachers' Interview (Question 7)

\begin{tabular}{lc}
\hline Do you think your students can understand the content of your class? & Frequency \\
\hline Yes & 5 \\
No & 2 \\
\hline
\end{tabular}

\section{Discussions and Conclusions}

According to the findings of the current study for the first research question, the teachers' perception about the use of code switching to facilitate English comprehension were mostly negative towards the teacher's persona and mostly positive about the subject access in these classes, and mostly negative about the ability of these teachers' ability of class management and also their attitudes were mostly negative towards interpersonal relations.

According to the findings of the current study for the second research question, the students' perceptions about the use of code switching to facilitate English comprehension were mostly negative towards the teacher's persona and mostly positive about the subject access in these classes, and mostly negative about the ability of these teachers' ability of class management and also their attitudes were mostly positive towards interpersonal relations.

According to the findings of the current study for the third research question, most of the teacher interviewed with the goal of encouraging mastery in the students, meaningful learning and transformational learning, "sometimes" used code switching mainly to explain difficult concepts and when they feel their students did not understand the materials. The most frequent cases in which the teachers were compelled to use Persian were to explain difficult concepts and when they felt their students did not understand the materials.

According to the findings of the current study for the forth research question, the students and teachers' opinions were mostly the same about the subjects related to teacher's persona in relation to using code switching and their opinions were not in line about the subjects related to classroom management in using code switching. About the subject access section, students more than teachers strongly disagreed, vice versa, in interpersonal relations' section, the students more than teachers agreed and strongly agreed about its relationship with teachers' code switching. 
The findings of the current research are comparable with the studies done by different scholars that some of them mentioned in the chapter two. These findings are in line with the study conducted by some researchers substantiated that code switching has positive effect on second language acquisition processes. As our student participants believed using code switching shows the deficiency of teachers, so our findings are in paradox with the idea proposed by Lai (1996), Brice and Roseberry-McKibbin (2001), and Widdowson (2003) who believed code switching should not be considered as a sign of defect in the teacher and instead, it is a careful strategy employed by the teachers. What is new with this study in comparison to previous literature review is that about all of the past studies on code switching investigated its effect on the process of language learning but there are very few studies to ask the attitudes of teachers or learners about teachers' code switching. This shortage is more tangible in the EFL context of Iran that no study can be viewed with this title and in Aviation University.

\subsection{Implications of the Study}

Based on the findings of this study, the attitudes of EFL students and teachers were not similar about the usefulness of using code switching in classroom management. But their opinions were in line about teacher's persona in using code switching. Therefore, the results of this study can be beneficial for all who communicate in a language and its understanding and usage is important for those who communicate in a second or foreign language in order to avoid misinterpretation. Hence, in the light of the findings of the current study, hopefully fruitful guidelines can be provided for instructors, students, and those who are involved in materials preparation.

In science and in reading education, as in education in general, a major goal is to make sure that students catch the input properly in order to establish it. As in this study, the teachers and students expressed, they believe code switching useful in certain cases as to elucidate grammatical, lexical and cultural points. The theoretical implication of the study can lead the pertinent researchers, experts and avid parties to prepare a framework about the areas allowed and not allowed to use code switching, as the teachers and learners both prefer to use it in certain cases and avoid overindulgence.

The results of this study can be useful for language learners to be aware of the role of using code switching in their process of language learning. By being aware of the attitudes of their teachers and the other students about using code switching, they may manage its use in their productions. In addition, the results of this study can be foremost beneficial for teachers to be aware of their students' attitude about using code switching in the classroom. These results can help them to identify the areas that the students have negative and positive attitudes about using code switching and to manage its usage to enhance and maximize the process of language learning. Regarding the results of this study, more areas of research can be recognized in order to help curriculum designers understand the considerable changes of learning environments and its impact on teaching and learning pedagogy. In this regard, curriculum designers can include linguistic behaviors in textbooks.

\section{References}

Auer, P. (1984). Bilingual conversation. Amsterdam: John Benjamins. http://dx.doi.org/10.1075/pb.v.8

Badrul Hisham, A., \& J. Kamaruzaman, J. (2009). Teacher's code-switching in classroom instructions for low proficiency learners. English Language Teaching, 2(2), 49-55.

Bloom, J. P., \& Gumperz, J. J. (1972). Social meaning in linguistic structure: Code switching in Northern Norway. In J. J. Gumpers \& D. Hymes (Eds.), Directions in sociolinguistics: The ethnography of communication (pp. 407-434). New York, NY: Holt, Rinehart, and Winston.

Brice, A., \& Roseberry-McKibbin, C. (2001). Choice of languages in instruction: one language or two? Teaching Exceptional Children, 33(4), 10-16.

Clyne, M. G. (1987). Constraints on code switching: how universal are they? Linguistics, 25(4), 739-764. http://dx.doi.org/10.1515/ling.1987.25.4.739

Gal, S. (1979). Language shift: Social determinants of linguistic change in bilingual Austria. New York: Academic Press. 
Rasouli, A., \& Simin, S.

Lai, M.-S. (1996). Using the L1 sensibly in English language classrooms. Retrieved from http://sunzi1.lib.hku.hk/hkjo/view/48/4800045.pdf

Gumperz, J. J. (1982). Discourse strategies. Cambridge: Cambridge University Press. http://dx.doi.org/10.1017/CBO9780511611834

Heller, M. (1988). Code switching: anthropological and sociolinguistic perspectives. Berlin: Mouton de Gruyter. http://dx.doi.org/10.1515/9783110849615

Mingfa, Y. (2011). On Attitudes to Teachers' Code-switching in EFL Classes. World Journal of English Language, 1, 19-28.

Myers-Scotton, C. (2006). Natural code switching knocks on the laboratory door. Bilingualism, Language and Cognition, 9(2), 203-212. http://dx.doi.org/10.1017/S1366728906002549

Poplack, Sh. (1980). Sometimes I'll start a sentence in Spanish y termino en espanol: Toward a typology of code switching. Linguistics 18, 581-618. http://dx.doi.org/10.1515/ling.1980.18.7-8.581

Romaine, S. (1995). Bilingualism. Oxford: Blackwell Publishers.

Ting, S. H. (2007). Influence of ethnicity and hierarchical status on language choice in a multilingual organization in Sarawak. Sarawak Museum Journal, 64(85), 221-250.

Valdés-Fallis, G. (1976). Social interaction and code-switching patterns: A case study of Spanish-English alternation in G. Keller, R. Teschener, \& S. Viera (Eds.), Bilingualism in the bicentennial and beyond (pp. 53-85). New York: Bilingual Press.

Widdowson, H. G. (2003). Defining issues in English language Teaching. Oxford: Oxford University Press. 
Appendix A: Questionnaire

\section{Section A: Demographic Data}

Please tick $(\sqrt{ })$ in the appropriate box or provide your details in the blanks.

Name:

Gender: Female $\square$ Male $\square$

Age: $20-25 \square$ 25-30 $\square$ 30-35 $\square$ 35-40 $\square$ 40-45 $\square$ above $\square$

\section{Completed by teachers:}

Teaching experience: below $5 \square 5-10 \square 10-15 \square$ 15- 20 $\square$ 20- $25 \square$ above $\square$

Currently Pursuing: Degree $\square$ Master $\square$ PhD

\section{Section B: leading questions}

\section{Part 1: Teacher' persona}

Question 1: Code switching enables the teachers to express themselves clearly in both languages. Strongly agree $\square$ Agree $\square$ Not sure $\square$ Disagree $\square$ Strongly disagree $\square$

Question 2: Teacher's code switching may causes difficulty in students' comprehension.

Strongly agree $\square$ Agree $\square$ Not sure $\square$ Disagree $\square$ Strongly disagree $\square$

Question 3: Teacher's code switching demolishes languages.

Strongly agree $\square$ Agree $\square$ Not sure $\square$ Disagree $\square$ Strongly disagree $\square$

Question 4: Teachers who use code switching are deficient in English.

Strongly agree $\square$ Agree $\square$ Not sure $\square$ Disagree $\square$ Strongly disagree $\square$

Question 5: Teachers who use code switching are proficient and capable in English.

Strongly agree $\square$ Agree $\square$ Not sure $\square$ Disagree $\square$ Strongly disagree $\square$

\section{Part 2: Subject access}

Question 6: Teachers who use code switching can do so in a wide range of points in class.

Strongly agree $\square$ Agree $\square$ Not sure $\square$ Disagree $\square$ Strongly disagree $\square$ 
Rasouli, A., \& Simin, S.

Question 7: Teachers who use code switching can better clarify the syntactic focuses and lexical things in the

content. $\quad$ Strongly agree $\square$ Agree $\square$ Not sure $\square$ Disagree $\square$ Strongly disagree $\square$

Question 8: Teachers who use code switching can better clarify social points in the content.

Strongly agree $\square$ Agree $\square$ Not sure $\square$ Disagree $\square$ Strongly disagree $\square$

Question 9: Teachers who use code switching can better evoke responses and reactions from students.

Strongly agree $\square$ Agree $\square$ Not sure $\square$ Disagree $\square$ Strongly disagree $\square$

Question 10: Teachers who use code switching can better illuminate the lesson substance taught.

Strongly agree $\square$ Agree $\square$ Not sure $\square$ Disagree $\square$ Strongly disagree $\square$

\section{Part 3: Classroom management}

Question 11: Teachers who use code switching can better elucidate assignment guideline.

Strongly agree $\square$ Agree $\square$ Not sure $\square$ Disagree $\square$ Strongly disagree $\square$

Question 12: Teachers who use code switching can better train students.

Strongly agree $\square$ Agree $\square$ Not sure $\square$ Disagree $\square$ Strongly disagree $\square$

Question 13: Teachers who use code switching can better engage students' consideration and attention.

Strongly agree $\square$ Agree $\square$ Not sure $\square$ Disagree $\square$ Strongly disagree $\square$

Question 14: Teachers who use code switching can better demand quiet.

Strongly agree $\square$ Agree $\square$ Not sure $\square$ Disagree $\square$ Strongly disagree $\square$

Question 15: Teachers who use code switching can better direct students.

Strongly agree $\square$ Agree $\square$ Not sure $\square$ Disagree $\square$ Strongly disagree $\square$

\section{Part 4: Code switching for interpersonal relations}

Question 16: Teachers who use code switching can better support and encourage students.

Strongly agree $\square$ Agree $\square$ Not sure $\square$ Disagree $\square$ Strongly disagree $\square$

Question 17: Teachers who use code switching can better acclaim students.

Strongly agree $\square$ Agree $\square$ Not sure $\square$ Disagree $\square$ Strongly disagree $\square$

Question 18: Teachers who use code switching can better enliven the atmosphere of class (e.g. make a joke for humor). $\quad$ Strongly agree $\square$ Agree $\square$ Not sure $\square$ Disagree $\square$ Strongly disagree $\square$ 
Question 19: Teachers who use code switching can better remark on the students' response and reaction.

Strongly agree $\square$ Agree $\square$ Not sure $\square$ Disagree $\square$ Strongly disagree $\square$

Question 20: Teachers who use code can better negotiate with students (decrease separation).

Strongly agree $\square$ Agree $\square$ Not sure $\square$ Disagree $\square$ Strongly disagree $\square$ 
Rasouli, A., \& Simin, S.

\section{Appendix B: Teacher's Interview}

The questions used in interviews were:

Question 1: How long have you been teaching English?

Question 2: What kind of course are you responsible for?

Question 3: What is your philosophy of teaching?

Question 4: How do you manage your language use in the classroom during language instruction?

Question 5: when do you use L1 in your class?

Question 6: How much L1 do you use in your class?

Question 7: Do you think your students can comprehend the substance of your class? 